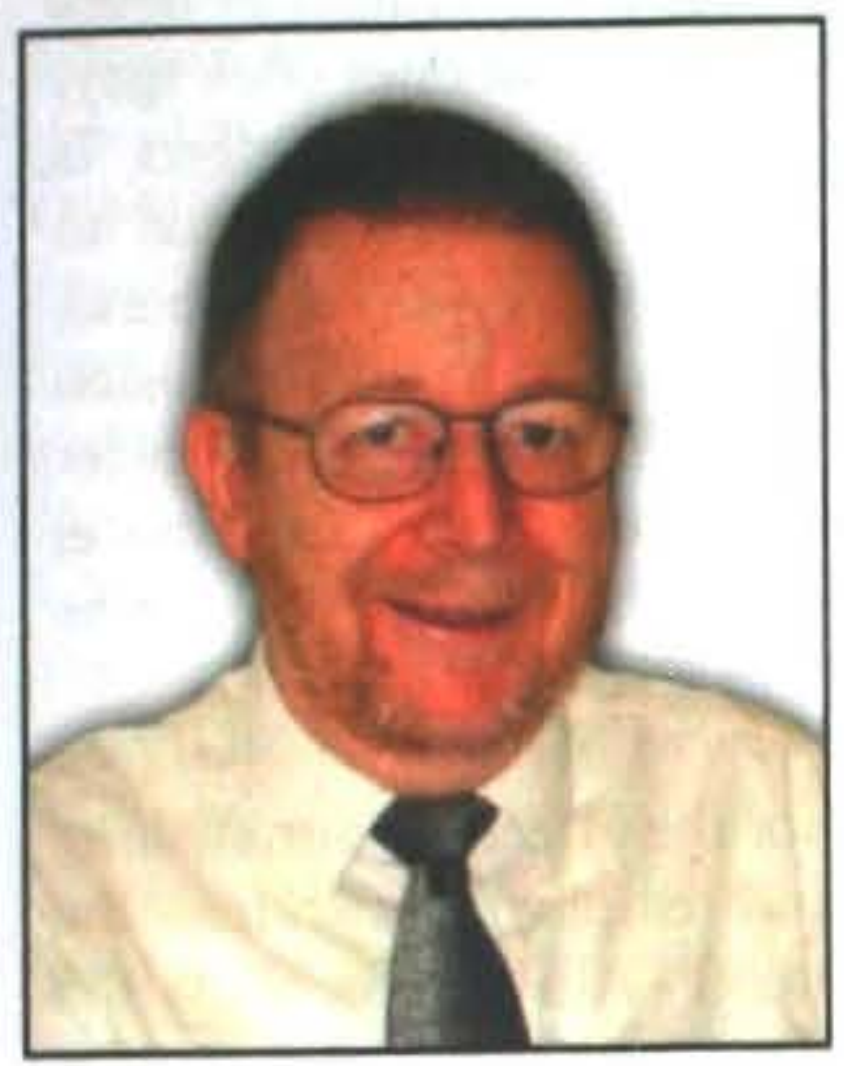

\section{THE IMPACT OF SKILLS ON RELATIVE PRODUCTIVITY PERFORMANCE AT NATIONAL LEVEL: EXPLORING CHANNELS OF INFLUENCE}

\author{
National Institute of Economic and Social
Research, London \\ Geoff Mason
}

Abstract

Given the widespread emphasis on the importance of increasing workforce skills in order to enhance productivity performance, it is perhaps surprising that the evidence on the contribution of human capital to inter-country differences in productivity performance is still mixed. Yet this is certainly the case. This paper argues that two main reasons why some studies fail to find a strong role for skills in explaining relative productivity performance at national level are difficulties in measuring skills adequately and failure to take account of the mechanisms or channels of influence by which skills may exert indirect effects on productivity. Examples of such channels of influence include the complementarities of skills with other production inputs and the contributions made by skilled workers to knowledge generation and exchange and to innovation processes. However, the paper cautions that, in any single country. increases in measured skills may indeed have no effect on relative productivity performance unless those skills are well matched to employer requirements and are effectively utilised within firms and other organisations.

\section{Introduction $^{1}$}

Policy-makers around the world now frequently emphasise the importance of increasing workforce skills in order to enhance productivity performance. In this context, it is perhaps surprising that so many controversies remain in assessing the scale and nature of the contribution of human capital to inter-country differences in productivity levels and growth rates. Yet this is certainly the case. Firstly, some studies of the sources of productivity gaps between countries do not find a strong role for inter-country differences in skills at all. Secondly, even taking account of those studies where positive effects of skills have been found, there is compelling evidence that increasing skills is rarely a sufficient means by itself of improving productivity performance. What matters is the way in which skilled labour is combined with other production inputs. In addition, due account needs to be taken of a number of diverse mechanisms by which skills may contribute indirectly to relative productivity.

rowth accounting-based estimates typically point to a limited role for human capital in explaining cross-country differences in performance. For example, Jorgenson, Ho and Stiroh (2005) find that the measured contributions of labour quality growth to average labour productivity growth in the US, UK, Germany and France between 1980-2001 were considerably smaller than the combined contributions of growth in ICT (information and communications technology) and non-ICT capital deepening on both sides of the Atlantic. Multivariate regression analysis is more likely to find a positive and significant impact of human capital on relative productivity levels, for example, in Mankiw, Romer and Weil's (1992) well known cross-sectional study of a large number of developed and developing countries. However, the panel data results reported by Islam (2003) suggest that growth in human capital has no significant effects on inter-country differences in productivity growth rates. In a substantial survey of research on the impact of human capital on macroeconomic performance, Sianesi and van Reenen (2003) emphasise the many methodological issues that remain unresolved in this field such as the measurement of skills and appropriate ways of modelling the different channels of influence of skills on productivity performance.

This paper assesses a number of potential explanations for the apparent difficulties in identifying links between human capital and productivity performance at country levei. It is ordered as follows: Section 2 reports on recent comparisons of relative productivity levels in the US and leading European countries. Subsequent sections then consider the effects of skills measurement problems (Section 3), complementarities between skilled labour and other production inputs (Section 4), the role of skilled labour in contributing to productivity performance through knowledge transfer and innovation (Sections 5 and 6) and mismatches between skills supply and demand (Section 7). Section 8 briefly summarises the main conclusions. 


\section{Accounting for cross-country gaps in labour productivity}

Conventional estimates of average labour productivity (ALP) levels show the US ahead of large European countries on output per worker but behind some or all of these European countries on output per workerhour (Table 1, Columns 1-6). The difference between the two measures reflects longer average annual hours worked per employee in the US compared to four of the five European countries (Table 1, Note b). As shown in Table 1 , this broad assessment is supported by three different sets of ALP estimates, all of which are sensitive to methodological choices made in estimation procedures and also in the compilation of the multi-country datasets on which they are based.

In recent years some researchers have developed alternative estimates of so-called 'structural' hourly productivity levels which take account of econometric evidence that ALP levels are negatively related to hours worked per employee and to employment rates (Belorgey, Lecat and Maury, 2006). While the hours effect is generally attributed to the effects of 'fatigue' (due to shorter holidays as well as longer daily working hours), the employment rate effect arises from the exclusion of less productive workers (e.g., younger or older workers) from employment in countries like France, Germany, Italy and Spain which have much lower employment rates than the US (Table 1, Note a).

When adjustments are made for the effects of diminishing returns to hours worked and employment rates, the resulting estimates of 'structural' ALP levels show the US ahead of all five European countries under consideration on the hourly productivity measure (Table 1, Columns 7-9) as well as on the ALP per worker measure (Bourles and Cette, 2005). It is therefore of considerable interest to evaluate the role of skills in contributing to continuing US productivity leadership over leading Western European economies.

Table 1: Relative labour productivity levels in France, Germany, Italy, Spain, UK and US, 2002 (Index numbers: $\mathrm{US}=\mathbf{1 0 0}$ )

\begin{tabular}{|c|c|c|c|c|c|c|c|c|c|}
\hline \multirow[b]{2}{*}{$\begin{array}{c}\text { Data source } \\
\text { (a) }\end{array}$} & \multicolumn{3}{|c|}{$\begin{array}{l}\text { Average labour productivity } \\
\text { per worker, } 2002\end{array}$} & \multicolumn{3}{|c|}{$\begin{array}{l}\text { Average labour productivity } \\
\text { per hour, } 2002\end{array}$} & \multicolumn{3}{|c|}{$\begin{array}{l}\text { 'Structural"' hourly } \\
\text { productivity, } 2002 \text { (b) }\end{array}$} \\
\hline & OECD & GGDC & $\begin{array}{l}\text { Euro- } \\
\text { stat }\end{array}$ & OECD & GGDC & $\begin{array}{l}\text { Euro- } \\
\text { stat }\end{array}$ & OECD & GGDC & $\begin{array}{l}\text { Euro- } \\
\text { stat }\end{array}$ \\
\hline France & 95 & 85 & 90 & 113 & 107 & 107 & 98 & 92 & 92 \\
\hline Germany & 79 & 81 & 74 & 93 & 105 & 92 & 81 & 92 & 80 \\
\hline Italy & 88 & 85 & 83 & 94 & 99 & 92 & 81 & 85 & 79 \\
\hline Spain & 79 & 71 & 74 & 74 & 747 & 74 & 68 & 68 & 68 \\
\hline UK & 78 & 75 & 79 & 79 & 86 & 84 & 77 & 84 & 82 \\
\hline US & 100 & 100 & 100 & 100 & 100 & 100 & 100 & 100 & 100 \\
\hline
\end{tabular}

Source: Bourles and Cette (2005).

Notes: (a) For details of the three sets of estimates based on OECD, GGDC (Groningen Growth and Development Centre) and Eurostat datasets, see Bourles and Cette, 2005. Table 1. (b) See text for discussion of the adjustments for hours worked per employee and employment rates underlying these estimates. Estimated average annual hours worked per employee in 2002 were: France 1437, Germany 1443, Italy 1599, Spain 1813, UK 1692 and US 1800. Employment rates as a percent of the $15-64$ year old population in 2002 were: France $62 \%$, Germany $65 \%$, Italy $56 \%$, Spain $60 \%$, UK $73 \%$ and US $72 \%$

In order to assess the contribution of different production inputs such as physical capital and human capital to relative labour productivity performance at sector and/or national level, a common starting point is the productivity levels equivalent of growth accounting. This method was first rigorously set out in Solow (1957) and has been widely used in productivity studies ever since, in particular by Jorgenson and his collaborators (see, for example, Jorgenson, et al, 2005). The theoretical underpinning for this approach is the neoclassical growth model, with underlying assumptions that all markets are competitive and that all factors in the production process are paid their marginal products, the sum of which exhausts all returns from pursuing those activities. In addition the use of value added to measure output involves the assumption that material input is separable from other inputs in the production function.

Under these assumptions, in a growth accounting model with two factors (capital and labour), it is possible to decompose cross-country differences in relative ALP levels into three components:

1. The proportion explained by differences in relative physical capital-intensity

2. The proportion explained by differences in relative labour quality (skills)

3. A residual MFP (multi-factor productivity) component which captures, among other things, cross-country differences in the efficiency with which existing production inputs are utilised. 
This methodology has been recently applied to a series of bilateral productivity comparisons between the UK and the US, France and Germany (Mason, O'Leary, O'Mahony and Robinson, 2008). This study finds that physical capital stocks per hour worked accounted for the largest shares of the UK-US, UK-France and UK-German gaps in ALP in market sectors. Residual MFP accounts for a large proportion of the productivity gap between the UK and the US while it has a smaller impact on the UKFrance comparison and a negative role in explaining the productivity gap between the UK and Germany. ${ }^{2}$ By contrast, inter-country differences in measured skills accounted for relatively small proportions of the ALP gaps in all three bilateral comparisons (Table 2).

Table 2: Decomposition of relative labour productivity levels in total market sectors (a), UK, US, France and Germany, 2002

\begin{tabular}{|c|c|c|c|}
\hline & U.S. & France & Germany \\
\hline $\begin{array}{l}\text { Relative ALP levels (value } \\
\text { added per hour worked) } \\
\text { - Index numbers: UK=100 }\end{array}$ & 133 & 123 & 110 \\
\hline \multicolumn{4}{|l|}{$\begin{array}{l}\text { Estimated contributions to } \\
\text { ALP gaps ( } \% \text { points): }\end{array}$} \\
\hline Physical capital & 15 & 14 & 22 \\
\hline Workforce skills & 2 & 2 & 2 \\
\hline MFP & 17 & 7 & -15 \\
\hline
\end{tabular}

Source: Mason, O'Leary, O'Mahony and Robinson (2008)

Notes: (a): 'Total market sectors' is here defined to exclude public administration, education and health and also real estate and residential buildings (NACE 70 in the European industrial classification) since, for national accounting purposes, this category includes the imputed rent of owner-occupied housing.

\section{Skills measurement issues}

As an intangible asset, human capital is notoriously difficult to measure. Typically, use is made of proxy measures of skill such as educational level, occupation and wages. The most common education-based measures of human capital can be divided between education inputs (for example, enrolments, years of schooling and indicators of education input quality such as class sizes) and education outputs (for example, formal qualifications, and indicators of education output quality such as test scores, literacy standards).

Discussions in this area are sometimes hampered by the use of terms like 'attainments' (an output concept) to refer to input measures such as years of completed schooling - a measure of attendance rather than attainment. Education output measures such as formal qualifications have the advantage of capturing something of what has actually been learned while undergoing education, rather than just signifying attendance. However, they have the equally clear disadvantage of ignoring skills acquired in the workplace without formal certification.
One approach to difficulties in measuring skills across countries is to take more care in data series construction in order to avoid sharp breaks and implausible changes in measured skill levels over very short periods of time that tend to reflect changes in data collection methods. De la Fuente and Domenech (2006) set out to do this by collecting information from both national and international publications as well as unpublished sources in order to obtain well-founded country-specific educational profiles for the adult population in 21 OECD countries. The information on attainment levels is then used to estimate the proportion of the population aged 25 and over that has started but not necessarily completed each of five different levels of education. Their results, based on multivariate regression analysis, point to a strong and positive impact of years of schooling on productivity, with a positive correlation between measures of the information content in different datasets and the size and significance of coefficients attached to the schooling variable. These findings support earlier work by Krueger and Lindahl (2001) which identified measurement error as a key reason why many earlier studies had found that increases in educational attainment had little or no impact on growth.

Another approach to skills measurement problems, as in Jorgenson et al (2005) and Mason et al (2008), is to make use of education output data (formal qualifications) combined with relative earnings data which are intended to capture differences in relative productivity between different qualification groups. Since individual productivity reflects the possession of uncertified skills as well as certified educational attainments, this approach should in principle help to overcome objections to relying on skill measures based solely on formal qualifications. Another problem arising in international comparisons of qualifications is that there is often no clear equivalence between qualification categories such as A levels in the UK, the Baccalaureate in France and high school graduates in the US. Therefore, Mason et al (2008) adopt an alternative approach of benchmarking on graduate-level qualifications (where comparability across countries is at its strongest), and then using ratios of mean wages in sub-graduate categories to mean graduate wages in each country as indicators of labour quality differences between the respective subgraduate qualification categories. This avoids having to try and classify non-comparable vocational and secondary education qualifications from different education systems into categories such as 'intermediate' and 'low' qualifications.

This approach to labour quality measurement represents, in principle, a considerable improvement on the use of unweighted education input or output data as proxy indicators of skills. However, it rests on two key underlying assumptions: (1) a broad similarity between countries in graduate-level productivity; and (2) that mean wage differentials between qualification categories reflect differences in the average productivity levels of persons classified to each qualification category. With regard to assumption (1), it can be argued that graduates are notably more mobile across national borders than those in other qualification groups and there is 
widespread acceptance by employers in the US and Western Europe of graduate-level qualifications from foreign countries. However, with regard to Assumption (2), employee wages may of course deviate from their marginal products due to imperfect labour market conditions and the operations of country-specific labour market institutions such as collective bargaining procedures and minimum wage legislation.

In spite of this shortcoming, wage-based measures of relative labour quality using graduate-level mean wages as a benchmark go some way towards capturing variations in relative marginal products across different sub-graduate qualification categories in each country. However, as shown in Section 2, when this improved labour quality measure is used for growth accounting purposes by Mason et al (2008), it still does not make a large contribution to explaining inter-country ALP gaps.

The main reason for this seems to be that, in the growth accounting framework, the respective contributions of each production input are evaluated separately without regard to potential complementarities between physical and human capital (for example, the ways in which skilled labour is a prerequisite for the selection, installation, operation and improvement of physical capital equipment). Multivariate techniques do provide scope for taking account of these complementarities. However, it is clear that more understanding is needed of the mechanisms by which skills might be expected to contribute indirectly to relative productivity performance. We now go on to consider some potential channels of influence of skills under two main headings: capital-skill complementarities and knowledge transfer and innovation.

\section{Capital-skill complementarities and skill- biased technical change}

Following Griliches (1969), much attention has been paid to the hypothesis of 'capital- skill complementarity' (CSC) under which physical capital and skilled labour are predicted to be more complementary to each other as production inputs than are physical capital and unskilled labour. As a proposition CSC is related to but separate from the notion of skill-biased technical change (SBTC), ie, the argument that skilled labour is more complementary to the introduction and/or effective utilization of new technologies than is unskilled labour.

Both the CSC and SBTC literatures are dominated by the experience of recent decades and thus benefit from some historical perspective. For example, Goldin and Katz (1998) report evidence that both CSC and SBTC were at work in US manufacturing between 1909 and 1940 as producers moved to continuous-process and batch methods of production and made greater use of electricity. Caselli (1999) points out that while some technological revolutions such as electrification and Information and Communication Technologies (ICTs) have been skill-biased in nature, others such as the development of assembly-line technology were more complementary to unskilled labour. Indeed, technologies of a 'de-skilling' kind tend to be introduced more quickly than do skill- biased technologies precisely because in the latter case the new required skills are likely to be costly and time-consuming to develop.

Recent estimates of ALP growth rates across countries show that, after a long period of relatively slow productivity growth, the US has benefited considerably from accumulated investments in ICTs. Between 1995-2004 the US recorded average annual growth of $3.1 \%$ in total market sectors, compared to $2.7 \%$ in the UK, $2.0 \%$ in France and $1.6 \%$ in Germany (Mason et al, 2008). On the basis of industry-level analyses, Jorgenson et al (2006) suggest that the relatively fast growth in US ALP during this period took the form of two different 'productivity surges'. The first surge between 1995-2000 was driven primarily by ICT capital-deepening and TFP growth in ICTproducing industries whereas the second surge between 2000-04 was more attributable to Non-ICT capitaldeepening and TFP growth in ICT-using industries. By contrast, the UK, France and Germany have tended to lag behind the US in terms of productive applications of ICTs outside ICT-producing industries as well as in ALP growth (O'Mahony and van Ark, 2003).

To what extent can these inter-country contrasts in ICT utilization, with their implications for relative productivity, be linked to different endowments of skills which might be complementary to ICTs? Table 3 shows the main differences in qualification levels and the composition of formal qualifications between the four countries. Throughout the 1995-2004 period the US was well ahead of the three European countries in terms of the university graduate share of employment, reflecting the established US system of mass higher education which built up over several preceding decades. The UK increased its graduate share of employment over this period (a process which began in the late 1980s) but is still well behind the US in terms of graduate- intensity of employment. Both France and Germany also have relatively small proportions of graduates by US standards but, in the German case, this is offset to some extent by a very large share of workers with intermediate-level (craft and technician) qualifications.

A long-running literature has highlighted the role of highly-educated or skilled workers in facilitating early adoption of new technologies in general (Nelson and Phelps, 1966; Bartel and Lichtenberg, 1987). More recent studies have focused on the role of skills in facilitating the effective utilisation of ICTs (for example, Brynjolfsson, Hitt and Yang, 2002) and the complementarity over several decades between ICTs and educated labour required to perform non-routine tasks (Autor, Levy and Murnane, 2003). However, Chun (2003) suggests that while ICT adoption is positively related to highly skilled workers, as the new technology becomes fully implemented, firms may be able to replace highly skilled workers with lower-paid less-skilled workers. According to this view, therefore, ICT-related demand for high-level skills may be a temporary phenomenon. This perspective finds support in Ruiz- 
Arranz (2004) who suggests that, as ICT equipment more accessible to

Table 3: Employment shares by qualification group, aggregate market sectors, 1995-2004

\begin{tabular}{|c|c|c|c|}
\hline & 1995 & 2000 & 2004 \\
\hline \multicolumn{4}{|l|}{ US } \\
\hline Higher degrees & 5 & 5 & 6 \\
\hline Bachelor degrees & 15 & 16 & 17 \\
\hline Associate degrees & 7 & 7 & 8 \\
\hline Some college but no degree & 22 & 21 & 21 \\
\hline High school & 35 & 34 & 33 \\
\hline Did not complete high school & 16 & 16 & 15 \\
\hline TOTAL & 100 & 100 & 100 \\
\hline \multicolumn{4}{|l|}{ UK } \\
\hline Higher degrees & 2 & 3 & 3 \\
\hline Bachelor (First) degrees & 10 & 12 & 13 \\
\hline $\begin{array}{l}\text { National Vocational Qualification Level 3-4 (Craft } \\
\text { and technician level) }\end{array}$ & 36 & 37 & 37 \\
\hline National Vocational Qualification Level 1-2 & 35 & 35 & 35 \\
\hline No qualifications & 18 & 13 & 12 \\
\hline TOTAL & 100 & 100 & 100 \\
\hline
\end{tabular}

\section{FRANCE}

\begin{tabular}{lccc} 
Higher degrees (Bac+5) & 3 & 3 & 4 \\
Bachelor degrees (Bac+3-4) & 9 & 11 & 11 \\
Bac+2 (Technician level) & 13 & 14 & 14 \\
Baccalaureate & 12 & 14 & 16 \\
CAP, BEP & 29 & 29 & 27 \\
Low or no qualifications & 34 & 28 & 27 \\
\hline
\end{tabular}

\section{GERMANY}

Higher degrees (Hochschulen)

Bachelor degree (Fachhochschulen)

Craft-skilled, Meister, Techniker

Low or un-skilled

\begin{tabular}{cccc} 
& 5 & 5 & 7 \\
& 4 & 5 & 5 \\
& 69 & 65 & 64 \\
& 22 & 25 & 24 \\
\hline TOTAL & 100 & 100 & 100
\end{tabular}

Sources: Mason et al (2008) derived from UK Labour Force Survey, US Current Population Survey, French Enquète-Emploi and the German Mikrozensus.

In order to assess the extent and nature of capital-skill complementarity across countries, Mason, O'Leary and Vecchi (2007) estimate wage share equations for different qualification groups with capital-output ratios included as independent variables, making use of a four-country dataset covering 26 manufacturing and service sectors over the period 1979-2000. Over this whole period they find that, in the UK and France, ICT investments were strongly complementary with the wage shares of wellqualified workers while tending to substitute for lowqualified workers. By contrast, in Germany there is no evidence at all of complementarity between ICT capital and the wage shares of skilled workers. Further research is needed to understand this finding for Germany but it may reflect the relatively large supply of craft-skilled workers relative to demand which existed prior to the diffusion of ICTs.

For the US Mason et al (2007) find a similar degree of ICT substitution for unskilled workers as in the UK and France but ICTs appear to be more complementary to intermediate groups in the US (for example, Associate degree holders and those who attended college without gaining formal qualifications) than to University graduates. Drawing on the same dataset, O'Mahony et al (2008) show that ICT-related demand for University graduates in the US was relatively strong in the first half of the 1979-2000 period but did decline relative to demand for workers with intermediate qualifications during the 1990s. 
Taken together these findings suggest that the US productivity resurgence in the late 1990s may have partly reflected, firstly, its early adoption of ICTs facilitated by the ready availability of college-educated workers and, secondly, its headstart in effective utilisation of ICTs resulting from this early adoption. As the process of improvements in utilisation has unfolded over time, the ICT capital-skill complementarity at work appears to have shifted towards workers with college education below four-year Bachelor degree level.

These different scenarios in each country illustrate the extent to which skill effects on relative productivity may change over time while also reflecting different national education and training institutions. The long timescales required for some skill differences to affect performance also emerge from consideration of skill effects on innovation to which we now turn.

\section{Skills, knowledge spillovers and innovation}

Skill-related externalities may occur if private sector decisions to invest in skills development yield benefits to individuals or employers other than those who have made the decisions to invest in skills formation. For example, the presence of skilled workers in workplaces may help to raise the productivity of unskilled co-workers. At the same time high-level skills may be a strategic complement to R\&D, with externalities arising from combined investments in skills by workers and in R\&D by employers.

Research on innovation has identified a number of different mechanisms by which skills- related externalities, or spillover effects, can affect performance. Examples include the transfer of knowledge between firms, sectors and countries through collaboration on R\&D and technical problem-solving among skilled workers involved in supply-chains (Lundvall, 1992) and the mobility of highly-qualified engineers and scientists between firms (Mason, Beltramo and Paul, 2004). Furthermore, in order for firms in each country to identify and make effective use of knowledge, ideas and technologies that become available through spillovers, what is required is 'absorptive capacity' which may be developed through organisations' own investments in R\&D (Cohen and Levinthal, 1989) and more generally through the development or acquisition of high levels of workforce skills.

Thus, for example, Benhabib and Spiegel (1994) find that human capital stocks are positively associated with individual countries' ability to narrow the gap between themselves and the world-leading nation in terms of productivity. Eaton and Kortum (1996) find that inward technology diffusion increases with a country's human capital. Xu (2000) provides evidence suggesting that the reason why relatively rich countries benefit more than poorer countries from hosting US multinational subsidiaries may be due to higher threshold levels of human capital in rich host countries.

The absorptive capacity literature initiated by Cohen and Levinthal (1989) puts particular emphasis on the two faces of R\&D', that is, the role of R\&D in both generating innovations and in enabling the assimilation of innovations generated elsewhere. In a recent crosscountry analysis at sector level between 1974-1990, Griffith et al (2004) explore the impact of absorptive capacity on MFP growth, expressed as a function of: (i) R\&D intensity (ii) an 'MFP gap' measure defined in terms of the gap in MFP levels between each country and the leader country, assumed to capture the scope for technology transfer (iii) human capital defined in terms of the percentage of the population that has participated in higher education, and (iv) the interactions between the MFP gap measure and, respectively, R\&D intensity and human capital. The results show that MFP growth is positively related to the size of the MFP gap, consistent with the convergence literature. More importantly, the coefficient on the MFP gap / R\&D intensity interaction term is positive, thus providing support for a key hypothesis relating to absorptive capacity, namely, that the further a country is behind the MFP leader in a particular industry, the greater is the contribution that R\&D makes to improving MFP growth performance. The coefficients on the human capital and R\&D intensity / human capital interaction terms are also positive and significant although not so high in absolute terms as those attached to absorptive capacity. Griffith et al conclude therefore that both R\&D and workforce skills help to stimulate productivity growth via their effects on innovation and absorptive capacity.

\section{Do skill needs vary with distance from the technological frontier?}

In recent years Vandenbussche, Aghion and Meghir (2006) have built on the work of Nelson and Phelps (1966) and endogenous growth theorists such as Romer (1990) and Aghion and Howitt (1992) to develop a model in which human capital contributes to multi-factor productivity (MFP) growth in different ways depending on how close countries are to the technological frontier. Their starting intuition is that countries close to the frontier are likely to rely more on innovation than imitation whereas the reverse is more likely for countries which are relatively distant from the frontier. Drawing on a 19-country dataset for the $1960-2000$ period, they find that MFP growth rates are negatively related (as expected) to each country's closeness to the technology frontier but are positively related to both the proportion of high-skilled (ie, tertiary-educated) labour and to a variable interacting proximity to the technology frontier with the proportion of high- skilled labour. They interpret this as evidence that high-skilled labour contributes more to MFP growth, the closer each country is to the technology frontier.

These findings have been challenged by Inklaar, Timmer and van Ark (2007) who note that Vandenbussche et al's estimates of residual MFP growth make no allowance for inter-country differences in hours worked per employee or in labour quality (educational attainment). Using an 11-country dataset for 9 service industries, Inklaar et al replicate Vandenbussche et al's approach using a more sophisticated MFP measure 
(which takes full account of indicators of labour input quantity and quality) and find that the human capital variable and the interaction term between proximity to the technological frontier and the proportion of highskilled labour are both no longer statistically significant. This applies whether analysing a country-level dataset or a cross-country set of market service sectors. Hence Inklaar et al's results provide no evidence of externalities from employing high-skilled workers.

Subsequently, Mason, O'Leary and Vecchi (2008) have drawn on a five-country sector- level dataset for 19792000 to regress the rate of growth of MFP on the technology gap at time $t-1$, the number of highly skilled workers as a proportion of total workers at time t-1 (highskill) and the interaction between the latter two terms. The distance of each country/sector from the technological frontier is defined as the gap between each country/sector MFP level and the MFP level of the frontier country/sector. ${ }^{3}$ All estimations are carried out using two stage least squares estimators, taking lagged values of the dependent variables as instruments.

As expected, the coefficients on the technology gap measure are positive and significant in all equations, providing further support for the idea that productivity laggards have greater scope for catching up with productivity leaders through successful absorption of knowledge and technologies generated elsewhere (Table 4). In contrast to Inklaar et al (2006), we find the coefficient on high-skilled labour to be positive and statistically significant at the $10 \%$ level, implying the presence of some externalities to the use of highskilled labour. At the same time however, the coefficient on the term interacting the technology gap and skilled labour measure is non-significant. Moreover, when the interaction term is introduced, the human capital externality effect disappears.

Thus no support is found for Vandenbussche et al's argument that the contribution of high-skilled labour to MFP growth is higher, the closer the country is to the technologicalfrontier. One possible reason for this is that, as discussed in Section 5, the skills required for successful absorption of knowledge and technologies generated elsewhere are non-negligible. Thus high-level skills may well have a part to play in facilitating others innovations.

\section{Mismatches between skills supply and demand}

In spite of the many positive effects of human capital on relative productivity discussed in Sections 4-5, there are also many ways that measured skills can increase without inducing any positive effects on productivity. For example, this can occur if the skills in question do not actually match the skill requirements of enterprises or if the proxy measures of skills in use such as formal qualifications convey an exaggerated impression of the quality of skills which are actually in use in the workplace.
Table 4: Estimating the impact of highly skilled human capital on MFP growth

(1)

(2)

\begin{tabular}{lccc}
\hline Technology gap (t-1) & $0.076^{* * *}$ & $0.073^{* * *}$ & $0.052^{*}$ \\
& $(0.027)$ & $(0.026)$ & $(0.032)$ \\
Highskill (t-1) & & $0.327 *$ & 0.231 \\
& & $(0.172)$ & $(0.211)$
\end{tabular}

Interaction of

technology gap and

highskill

\begin{tabular}{lccc} 
Observations & 1911 & 1911 & 1911 \\
AndersonLR Statistic & 410.968 & 400.045 & 396.101 \\
Statistic $\left(\chi^{2}\right)$ & $(0.000)$ & $(0.000)$ & $(0.000)$ \\
HansenJ Statistic $\left(\chi^{2}\right)$ & 0.316 & 0.271 & 0.302 \\
& $(0.574)$ & $(0.603)$ & $(0.859)$ \\
\hline
\end{tabular}

Notes: $* * *=$ significant at $1 \%, * *=$ significant at $5 \%, *=$ significant at $10 \%$. Heteroscedasticity-robust standard errors, corrected for clustering, are in brackets. All variables have been instrumented with their own value at time t-2 and t-3. For details of the Anderson LR statistic and the Hansen J statistic, see notes to Table 1 .

These issues have arisen very strongly in the UK following a rapid transition from elite higher education to mass higher education between the mid-1980s and mid1990s. By the year 2000 graduates represented $15 \%$ of the total workforce in the UK, up from just under $10 \%$ ten years earlier. ${ }^{4}$ One consequence of this development has been increasing reports of 'underutilisation' of the skills of some graduates who find employment in relatively low-skilled jobs. Another has been complaints from some employers that a proportion of newly-produced graduates do not possess the level of skills traditionally associated with graduates. These concerns can be exaggerated and detailed assessments of the UK graduate labour market suggest that the expansion of graduate output has also had some positive effects on skills supply and job performance (Mason, 2002; Elias and Purcell, 2004). However, the point remains that increases in the output of certain qualifications, showing up as increases in measured skills, may or may not contribute positively to productivity performance.

One way to assess this on a cross-country comparative basis is to consider evidence on the extent to which university graduates, and indeed other skilled workers as well, are in relatively low-paid employment, implying that their productivity is relatively low. Here we draw on national labour market studies which have adopted a standard definition of 'low pay', namely, gross hourly earnings lower than two thirds of median gross hourly earnings in each country. Table 5 shows that in recent years only about $4-6 \%$ of graduates or those educated to tertiary level in the US, UK, France and Germany are low-paid by this definition. However, the proportions in low-paid employment are much greater for high school graduates in the US (18\%) and holders of craft-skilled or equivalent qualifications in the UK $(20 \%)$ and Germany 
$(18 \%)$. These are non-negligible proportions of formally qualified workers in low-paid employment and, assuming that relative pay bears some relation to relative productivity in each country, the results serve as a reminder that efforts to raise skills by increasing the output of formally qualified workers may not always contribute positively to productivity performance.

Table 5: Proportion of workforce in low-paid employment, US, UK, France and Germany, analysed by qualification group (a)

\begin{tabular}{lc}
\hline & $\begin{array}{c}\% \text { of workforce in low- } \\
\text { paid employment (b) }\end{array}$ \\
\hline US (2001) & 6 \\
$\begin{array}{l}\text { Tertiary education (Bachelor } \\
\text { degrees, Associate degrees, some } \\
\text { college education without degree) }\end{array}$ & \\
\hline UK (2005) & 5 \\
University graduates & 20 \\
$\begin{array}{l}\text { NVQ Level 3 (A levels, craft- } \\
\text { skilled, or equivalent) }\end{array}$ & \\
\hline FRANCE (2002) & 4 \\
Tertiary education (Bac+2 or \\
higher) \\
Baccalaureate \\
\hline GERMANY (2003) \\
$\begin{array}{l}\text { Graduates (Hochschule or } \\
\text { Fachhochschule) } \\
\text { Craft-skilled }\end{array}$ \\
\hline
\end{tabular}

Sources: Derived from papers prepared for Russell Sage Foundation project on Low-Wage Employment in the United States and Western Europe by John Schmitt; Geoff Mason, Ken Mayhew and Matthew Osborne: Philippe Askénazy, Eve Caroli and Jérôme Gautié; and Gerhard Bosch and Thorsten Kalina.

Notes:

(a) Refers to all employees (full-time plus part-time) in each country except for Germany where only full- time employees covered by the social security system are included and France where apprentices are excluded.

(b) Low-paid employment is defined as having gross hourly earnings lower than two thirds of median gross hourly earnings in each country.

\section{Assessment}

It is by no means easy to assess the scale and nature of the contribution of human capital to inter-country differences in productivity levels and growth rates. This survey of relevant literature and research findings suggests that there are many positive effects of human capital on relative productivity at country level. However, these effects only emerge clearly when efforts are made to improve the measurement of skills and to identify the main channels of influence by which skills may affect performance indirectly as well as directly (for example, through the complementarities of skills with other production inputs and the contributions made by skilled workers to knowledge generation and exchange and to innovation processes). At the same time increases in measured skills may have no effect on relative productivity performance unless those skills are well matched to employer requirements and are effectively utilised within enterprises.

\section{Notes}

1. This paper draws in part on joint work with Mary O'Mahony, Michela Vecchi, Kate Robinson and Brigid O'Leary at the National Institute of Economic and Social Research. Responsibility for errors in the present paper is mine alone.

2. The negative MFP contribution in the UKGerman comparison suggests that, while Germany benefits relative to the UK from its accumulated advantages in capital stocks and (to a much lesser extent) skills, the UK gains from more efficient use of its capital equipment and skilled labour. However, the UK still pays a penalty in ALP terms for having accumulated relatively low levels of physical capital and skills over time.

3. The five countries are UK, US, France, Germany and the Netherlands. In total the dataset covers 26 sectors in both manufacturing and services in each country.

4. Estimates derived from UK Labour Force Survey as in Table 3.

\section{References}

Autor, D., Levy, F. and Murnane, R. (2003), The skill content of recent technological change: an empirical explanation, Quarterly Journal of Economics, 118(4): pages 1279-1333.

Bartel, A. and F. Lichtenberg. (1987). The comparative advantage of educated workers in implementing new technology. Review of Economics and Statistics. LXIX 1:1-11.

Belorgey, N., Lecat, R. and Maury, T-P. (2006), Determinants of productivity per employee: An empirical estimation using panel data, Economics Letters, 91(2):153-157

Benhabib, J. and Spiegel, M. (1994), The Role of Human Capital in Economic Development: Evidence from Aggregate Cross-Country Data, Journal of Monetary Economics, 34, pp 143-173.

Bourles, R. and Cette, G. (2005), A comparison of structural productivity levels in the major industrialised countries, Banque de France, Notes d'Etudes et Recherches, R\#133, October 2005.

Brynjolfsson, E. and Hitt, L. (2000), Beyond computation: information technology, organizational transformation and business performance, Journal of Economic Perspectives 
Caselli, F. (1999), Technological Revolutions, American Economic Review, 89, 1: 80-102.

Chun, H. (2003) Information technology and the demand for educated workers: disentangling the impacts of adoption versus use, The Review of Economics and Statistics, 85 (1), 1-8.

Cohen, W. and Levinthal, D. (1989): Innovation and learning: two faces of R\&D, Economic Journal, vol, 107, 139-149.

De la Fuente, A. and Domenech, R. (2006) Human Capital in Growth Regressions: How Much Difference Does Data Quality Make? Journal of the European Economic Association, vol 4(1), 136.

Eaton, J. and Kortum, S. (1996) Trade in ideas: productivity and patenting in the OECD, Journal of International Economics

Elias, P. and Purcell, K. (2004) Is Mass Higher Education Working? Evidence from the Labour Market Experiences of Recent Graduates, National Institute Economic Review, 90: 60-74.

Goldin, C. and Katz, L. (1998), The origins of technology-skill complementarity, Quarterly Journal of Economics 113, 693-732.

Griffith, R., Redding, S. and van Reenen, J. (2004), Mapping the Two Faces of R\&D: Productivity Growth in a Panel of OECD Industries Review of Economics and Statistics, 86(4), 883 - 895.

Griliches, Z. (1969): Capital Skill complementarity Review of Economics and Statistics, vol. 51, 465-467.

Islam, N. (2003) Productivity dynamics in a large sampel of countries: a panel study Review of Income and Wealth, Series 49, No. 2

Jorgenson, D., Ho, M. and Stiroh K. (2005), Productivity: Information Technology and the American Growth Resurgence, Cambridge, MA: MIT Press.

Jorgenson, D., Ho, M., Samuels, J. and Stiroh, K. (2006), The industry origins of the American productivity http://post.economics.harvard.edu/faculty/ jorgenson/papers/IndustryOriginsAmerProdResurg 100206.pdf

Krueger, A. and Lindahl, M. (2001) Education for Growth: Why and For Whom? January, 2000. Journal of Economic Literature 39(4)

Lundvall, B-A. (1992), National Systems of Innovation: Towards a Theory of Innovation and Interactive
Mankiw, N. G., Romer, D. and Weil, D. (1992). A contribution to the empirics of economic growth, Quarterly Journal of Economics, 107, 407-437.

Mason, G. (2002), High skills utilisation under mass higher education: graduate employment in service industries in Britain, Journal of Education and Work, 2002,15(4): 427-456.

Mason, G., Beltramo, J-P. and Paul, J-J. (2004), External knowledge sourcing in different national settings: a comparison of electronics establishments in Britain and France, Research Policy, 2004, 33(1): 53-72.

Mason, G., O'Leary, B., O'Mahony, M. and Robinson, K. (2008), Cross-country productivity performance at sector level: the UK compared with the US, France and Germany, London: Department of Business, Enterprise and Regulatory Reform.

Mason, G., O'Leary, B. and Vecchi, M. (2008a), Crosscountry analysis of productivity and skills at sector level, Research Report No. 23, Sector Skills Development Agency, London.

Mason, G., O'Leary, B. and Vecchi, M. (2008b), Revisiting the impact of human capital on productivity: new cross-country evidence at sector level, London: NIESR (mimeo)

Nelson, R.R. and Phelps, E.S. (1966). Investments in humans, technology diffusion and economic growth, American Economic Review, LVI, 69-75.

O'Mahony, M. and van Ark, B. (2003), EU Productivity and Competitiveness: A Sectoral Perspective. Can Europe Resume the Catching-up Process? The European Commission, Luxembourg.

O'Mahony, M., Robinson, K. and Vecchi, M. (2008), The impact of ICT on the demand for skilled labour: a cross-country comparison, Labour Economics (forthcoming).

Ruis-Arranz, M. (2004) Wage Inequality in the US: Capital-Skill Complementarity vs Skill-biased Technical Change IMF mimeo, May 2004

Sianesi, B. and Van Reenen, J. (2003). The returns to education: macroeconomics, Journal of Economic Surveys, 17, 157-200.

Solow, R. (1957). Technical change and the aggregate production function, Review of Economics and Statistics, 39, 312-320.

Xu, B. (2000): Multinational enterprises, technology diffusion and host country productivity growth, Journal of Development Economics, 62, 477-49. 
Author

Geoff Mason

Senior Research Fellow

National Institute of Economic and Social Research

2 Dean Trench Street

Smith Square

London SW1P 3HE

United Kingdom

gmason@niesr.ac.uk 